Turner's contribution to nature study. Mr. Bonacina's detailed discussion of notable examples of Turner's pictures in the National Gallery, the Tate Gallery, and the Victoria and Albert Museum deserves the careful consideration of students of both science and art. The attention of these specialists and also of persons of general culture may properly be directed to the following sentence in which the outlook of the author is strikingly expressed: "the co-ordination and unification of truth acquired on the one hand through scientific research and on the other expressed through artistic intuition are the intellectual needs of the age".

\section{Recent Work in Meteorology}

THE annual report of the Director of the Meteorological Office for the year ended March 31, 1938, describes the work of a period during which attention has been focused on the ever-growing needs of the rapidly expanding Royal Air Force and civil aviation. Many new meteorological stations were opened during that period on service and civil aerodromes as trained staff became available. The installation of direct teleprinter connexions between the meteorologieal stations in the country and the Air Ministry Meteorological Office headquarters was begun and arrangements for its extension to the constantly growing network of similar stations had to be considered. Meteorological information for the trans-Atlantic flights of July 1937 was supplied from stations set up at the Shannon Airport and at Botwood. The first of these was worked on an agency basis by the Meteorological Office for the Government of Eire, and the second was operated by the Canadian Meteorological Service on behalf of the Government of Newfoundland. Conferences were held afterwards at Toronto and Dublin to review the meteorological organization and improve it.

ON the research side, important work was done in collaboration with the National Physical Laboratory in developing apparatus for measuring upper air conditions by radio instruments carried on unmanned balloons, so as to obtain immediate information about wind, pressure and temperature up to greater heights than could be reached when observations were made in aeroplanes. An additional advantage from the new methods is that the information can be obtained in weather dangerous for flying. Climatic conditions in Africa during years when there were serious outbreaks of locust swarms were under investigation on behalf of the Committee on Locust Control.

\section{Electric Heating for Merchant Ships}

THE heating installation of a merchant ship is very different from that of a building on shore. An ocean. going merchant ship may sail into cold weather at any time of the year. In the course of a week she may sail from tropical heat into almost arctic conditions ; and in a voyage of a month's duration she may sail from winter in one hemisphere, through spring, summer and autumn, or vice versa, and come into winter conditions in the other hemisphere. A paper on this subject was read to the Institution of
Electrical Engineers on November 24 by $H$. C. Macewan. A difficulty of arriving at a simple method of calculation, like that used for computing the electric heating for a building, arises from the fact that the regulations quoted in specifications are very vague. Recently the British Board of Trade stated in its instructions to its surveyors in relation to master's and crew's spaces that "a heating system will be considered satisfactory if it is capable of maintaining a temperature of $60^{\circ} \mathrm{F}$., when the tem. perature of the outside air is $30^{\circ} \mathrm{F}$." This, although a useful help for making calculations, is insufficient as the basis for a test to show the adequacy of the heating. Mr. Macewan has collected data for the calculation of quantities and gives a general review of the problem as it exists to-day. He points out that the capital cost of the electric heating of ships is usually less than that of other systems as it is cheaper to run electric cables than pipes. In running cost also, electric heating is cheap, as it usually acts as a 'demand leveller' and it is seldom necessary to run an extra generator.

\section{Broadcasting in India}

Is Electrotechnics, the journal of the Electrical Engineering Society of the Indian Institute of Science, Bangalore, of April, we learn that the Government of India is making progress with the construction of broadcasting stations. In December 1937, the 5-kw. medium-wave transmitter at Lahore and the 10-kw. short-wave station at Delhi commenced operation. The short-wave station at Bombay-also of $10 \mathrm{kw}$. - started to radiate early in February, and Lucknow early in April. The 0.25-kw. medium-wave and the 10-kw. short-wave transmitters at Madras were put into regular service from the middle of June. The Trichinopoly 5-kw. medium-wave station is expected to commence operation at an early date. Several Provincial Governments have already distributed a small number of receivers for group listening in villages. The broadcasting authorities of the Central Government have under way a programme for installing 120 receivers in as many villages in the Delhi Province. At the present moment, the broadcasting service touches but a fringe of the population and the programmes are of limited appeal. The element of novelty and wonder is still the dominating factor in reception amongst all classes of listeners. Listening for pure entertainment and enjoyment, oblivious to the mechanism, is as yet virtually non-existent in India. Until the present uncritical listening gives place to the habit of tuming to radio for enjoyment, such questions as the acoustical requirements of studios and the special requirements demanded by Indian music and its technique can receive no adequate and satisfactory answer. In this journal, Mr. K. Sreenivasan's thoughtful address on the design of studios for broadcasting is published.

\section{Oxford Science}

THE first number of a new shilling quarterly called Oxford Science, edited and published by the Junior scientific Club, and printed at the Oxford University 
Press, appeared this week. All new journals of this kind are necessarily precarious ventures, but there are good hopes that this one will fulfil the need it has been produced to meet. It is taking the place of the Transactions of the Club, which have been published now for more than fifty years. It will contain the more important lectures given from time to time to the Club, discuss problems connected with study and research in science and medicine at Oxford and review the work of the different scientific departments. The opening number contains the Robert Boyle lecture by Sir Edward Mellanby on methods of discovery in the fight against disease, an article by Prof. F. Paneth on atomic transmutation, an account of recent investigations on the structure of proteins by D. Parker Riley and an article discussing and criticizing medical curricula by one of the medical tutors. Some of the articles are illus. trated. There are also editorial and other notes and a few book reviews. Altogether this is a lively first number that should make a wide appeal to the student of science interested in other sciences besides his own and in the problems that their impact on the world and the university has produced.

\section{Gardeners of Essex}

THE presidential address of Dr. John Ramsbottom to the Essex Field Club provided an opportunity to present much historical gardening knowledge in a pleasant, intimate form ("Old Essex Gardeners and their Gardens", Essex Naturalist, 26, 65-103 ; 1938). Yucca first flowered in England during the year 1604, in the garden of William Coy at Stubbers, North Okington. This same garden also enjoys the distinction that it was the source whence the ivyleaved toadflax, Linaria cymbalaria, first spread to become apparently native upon walls throughout England. It would be difficult to over-estimate the valuable work of another Essex gardener, Lord Petre, who stimulated the collection of many foreign plants which have become accepted beautifiers of British gardens. Richard Warner of Woodford introduced the genus Gardenia to English horticulture in 1754, and Dr. John Fothergill, 1712-80, had an influence similar to that of Lord Petre. He stimulated numerous useful projects, and himself cultivated many new and curious plants. No geographical limits were set by these Essex plant collectors, but they appear to have been especially responsible for the introduction of North American species to the gardens of Europe.

\section{National Planning}

THe Town Planning Institute has issued a report of the National Survey and National Planning Committee (price 1s.). The report stresses several matters of importance, and points out that in England and Wales (for Scotland is not included) about three quarters of the local authorities have applied the various Acts to about two thirds of the total land area. The process of planning, however, appears to be slow and essentially local in outlook. The Committee believes that national planning is required to supplement and reinforce local and regional planning. There is no national policy or guidance in the preserva. tion of land for agriculture and for the reservation of national parks and other large open spaces. Further, in problems of transport, such as roadways and airports, a national, rather than a regional, outlook is necessary. The report contains a strong plea for a new department of Government which should take the form of a National Planning Commission. Its functions would be, first, the completion of a national survey, and secondly, advice and guidance to other Government departments and local authorities. Thus it would be possible to formulate and execute a national policy in the utilization of land.

\section{Earthquake in the East Indies}

The U.S. Coast and Geodetic Survey, Washington, D.C., has announced the occurrence of an earthquake on October 10d. 20h. $48 \mathrm{~m}$. G.C.T. with provisional epicentre lat. $1^{\circ} \mathrm{N}$., long. $125^{\circ} \mathrm{E}$. The epicentre was determined from instrumental data obtained at twelve United States seismological observatories. The epicentre is to the west of the Molucca Passage and the nearest town of any size is Menada in the north of Celebes. No damage has so far been reported from here. According to Dr. $\mathrm{S}$. W. Visser and his colleagues of the seismological observatory at Batavia, small earthquakes are quite frequent near this spot. World-shaking earthquakes are somewhat infrequent, however, and the last ones were the swarm of July 10-12, 1926, epicentre lat. $1^{\circ} \mathrm{N}$., long. $126^{\circ} \mathrm{E}$. It is possible that the earthquake on July 10,1926 , was multiple, as the $P$ residuals appear to show groupings which are confirmed by the $S$ residuals.

\section{Traffic in Women and Children}

ThE League of Nations Committee for the Sup. pression of Traffic in Women and Children recently proved by investigation that there is a connexion between licensed houses of prostitution and traffic in women. The League, therefore, sought information from many Governments and voluntary associations respecting the early lives of women who afterwards became prostitutes, and has issued an analysis of this information, with comments, in a report recently issued ("Prostitutes : their Early Lives". Geneva, 1938. London: Allen and Unwin. 3s.). Some 60 per cent of the women were considered to be below normal in intelligence. Poverty and destitu. tion, early seduction, and the desire for an easy life seem to be the main causes responsible for women adopting this kind of life.

\section{Monkeys as Botanical Collectors}

The Kew Bulletin No. 7, 1938, quotes from the annual report of the Director of Gardens, Straits Settlements, an account given by the acting director, Mr. E. J. H. Corner, of the use made of berols monkeys (Macacus nemestrina) to collect specimens from tall trees. Two young beroks are at present employed; they understand twelve words of Kelantanese and can thus be instructed to pick specific twigs and drop them to the ground. Mr. Corner states, "A berok upon the shoulder can be likened, in effect, to a falcon on the wrist; and its employment is recommended both to amateurs for its charm and cheap- 